\title{
Impact of Chemical Coagulants for Oscillatoria sp. Removal from Raw Water on Chemical Coagulation Process
}

\author{
Saowapak Thammasane and Thaniya Kaosol \\ Department of Civil Engineering, Faculty of Engineering, Prince of Songkla University, Songkhla, Thailand
}

\author{
Article history \\ Received: 12-11-2018 \\ Revised: $15-11-2018$ \\ Accepted: 12-12-2018 \\ Corresponding Author: \\ Thaniya Kaosol \\ Department of Civil \\ Engineering, Faculty of \\ Engineering, Prince of Songkla \\ University, Songkhla, Thailand \\ Email: thaniya.k@psu.ac.th
}

\begin{abstract}
Growing Oscillatoria sp. in freshwater causes several poisoning episodes of domestic livestock animal and human. The chemical coagulation of raw water using chemical coagulants is very simple and requiring less investment cost on equipment. These experiments used alum and PACl (Polyaluminium chloride) with alum as chemical coagulants for Oscillatoria sp. removal. The Oscillatoria sp. was prepared from Molecular and Cell Laboratory of Thailand Institute of Scientific and Technological Research and grown in BG-11 medium. The samples of treated water use chemical coagulation test to verify their efficiency of Oscillatoria sp. cells removal from the synthetic raw water. The results show that the chemical coagulation using alum coagulant and $\mathrm{PACl}$ with alum coagulants produces a high efficiency in Oscillatoria sp. removal. However, the $\mathrm{PACl}$ with alum coagulants provided the best Oscillatoria sp. removal efficiency and the low amount of chemical coagulants for Oscillatoria sp. removal process. The PACl with alum doses at 1:10 by weight, provides the best Oscillatoria sp. removal efficiency at $97 \%$. While, the best Oscillatoria sp. removal efficiency of alum dose at $90 \mathrm{mg} / \mathrm{L}$, is $98 \%$. It can be concluded that the $\mathrm{PACl}$ with alum doses as the combined chemical coagulant provided the highest efficiency at the lowest amount of chemical coagulants used.
\end{abstract}

Keywords: Oscillatoria sp., Chemical Coagulation, Alum, PACl, Chlorophyll A

\section{Introduction}

Algae are aquatic plants and photosynthetic that utilize inorganic nutrients such as phosphorus and nitrogen. Cyanobacteria, also known as blue-green algae, are a morphologically diverse group of photosynthetic prokaryotes that occupies a wide range of niches, from freshwater to hydrothermal vents. Some cyanobacteria produce toxins, called Cyanotoxins. Their most common toxic cyanobacteria in freshwater or surface waters are Oscillatoria sp., Microcystis sp., Anabaena sp., Lyngbya sp., Aphnizomenon sp., Schizothrix sp. and Nostoc sp. The toxicity cannot be excluded for the further species and genera (WHO, 1998). About $75 \%$ of all cyanobacteria sample contain toxin, it is the huge conglomerations of cells that present a great concern of large blooms development in summer (Chorus et al., 2000). The toxin production of cyanobacteria creates a risk on human and animal health. Several poisoning episodes of domestic animals and livestock have been associated with the occurrence of cyanobacteria blooms in surface waters used for drinking (Stewart et al., 2008).
Oscillatoria sp. is one kind of cyanobacteria. The Oscillatoria sp. blooms occur in freshwater. The growth of Oscillatoria sp. tends to occur in late summer when there are high concentrations of nutrients, particularly phosphorus, high water temperature, long hydraulic retention time and stable water body stratification (Chorus and Bartram, 1999; Villareal and Capenter, 2003). Due to these characteristics, Oscillatoria sp. trend to occur more often in reservoirs, lakes, ponds and dams (Pumas et al., 2011). The Oscillatoria sp. growth can be increasing because of the nutrients in the water bodies that are influenced by the fertilizer and chemical fertilizer carried by discharges of runoff or subsurface infiltration of groundwater (Naz et al., 2015).

The concentration of Oscillatoria sp. was about 4,500 cell $/ \mathrm{mL}$. Even a very low concentration of Oscillatoria sp. in water (e.g., a few nanograms per liter) can cause taste and odor in water that are associated with adverse human health effects (WHO, 2015). These tastes and odors can lead to the complaints from the customers or result in consumers using an aesthetically more acceptable, but potentially less safe, drinking-water 
source in the Southern Region Industrial Estate, Songkhla Province, Thailand.

The chemical coagulation can be an effective method for algae removal, although care must be taken to remove these organisms without disrupting the algae cells. The general chemical coagulation does not appear to cause the release of algae toxins, when the oxidants are not added (Carmichael, 2001). An effective method for removing intact cyanobacteria cells from drinking water is the coagulation with iron salts and alum followed by conventional flocculation and sedimentation (Drikas et al., 2001). Aluminum sulfate or alum is the most commonly used chemical coagulant and is easy to handle and apply and produces less sludge than lime.

The aim of this work is to test the chemical coagulants used for removing the Oscillatoria sp. from the synthetic raw water for water supply using jar test. The jar test is used to identify the most adapted mix of chemical coagulants and concentrations for coagulation-flocculation. The batch the test, using several identical jars with the same volume and concentration of feed, are used in this study. The results focus on the removals of chlorophyll $\mathrm{A}$ and algae cell.

\section{Experiments}

\section{Microorganism}

The Oscillatoria sp. (Fig. 1) culture used in this study was collected from Thailand Institute of Scientific and Technological Research. Pure culture was grown in BG11 medium containing $\mathrm{NaNO}_{3}(1.5 \mathrm{~g} / \mathrm{L}), \mathrm{K}_{2} \mathrm{HPO}_{4}(0.04$ $\mathrm{g} / \mathrm{L}), \mathrm{MgSO}_{4} \cdot 7 \mathrm{H}_{2} \mathrm{O}(0.075 \mathrm{~g} / \mathrm{L}), \mathrm{CaCl}_{2} \cdot 2 \mathrm{H}_{2} \mathrm{O}(0.036 \mathrm{~g} / \mathrm{L})$, citric acid $(0.006 \mathrm{~g} / \mathrm{L})$, ferric ammonium citrate $(0.006$ $\mathrm{g} / \mathrm{L}), \operatorname{EDTANa}_{2}(0.001 \mathrm{~g} / \mathrm{L}), \mathrm{Na}_{2} \mathrm{CO}_{3}(0.02 \mathrm{~g} / \mathrm{L})$ and trace metal mix $1 \mathrm{~mL} / \mathrm{L}$. The composition of trace metal mix is $\mathrm{H}_{3} \mathrm{BO}_{3}(2.86 \mathrm{~g} / \mathrm{L}), \mathrm{MnCl}_{2} \cdot 4 \mathrm{H}_{2} \mathrm{O}(1.81 \mathrm{~g} / \mathrm{L})$, $\mathrm{ZnSO}_{4} \cdot 7 \mathrm{H}_{2} \mathrm{O}(0.222 \mathrm{~g} / \mathrm{L}), \mathrm{Na}_{2} \mathrm{MoO}_{4} \cdot 2 \mathrm{H}_{2} \mathrm{O}(0.39 \mathrm{~g} / \mathrm{L})$ and $\mathrm{CuSO}_{4} \cdot 5 \mathrm{H}_{2} \mathrm{O}(0.079 \mathrm{~g} / \mathrm{L}), \mathrm{Cu}\left(\mathrm{NO}_{3}\right)_{2} \cdot 6 \mathrm{H}_{2} \mathrm{O}(0.0494$ $\mathrm{g} / \mathrm{L})$. Figure 2 shows the Oscillatoria sp. cultivation.

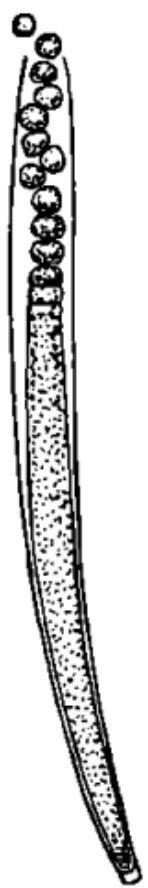

Fig. 1: The Oscillatoria sp. (Chorus and Bartram, 1999)

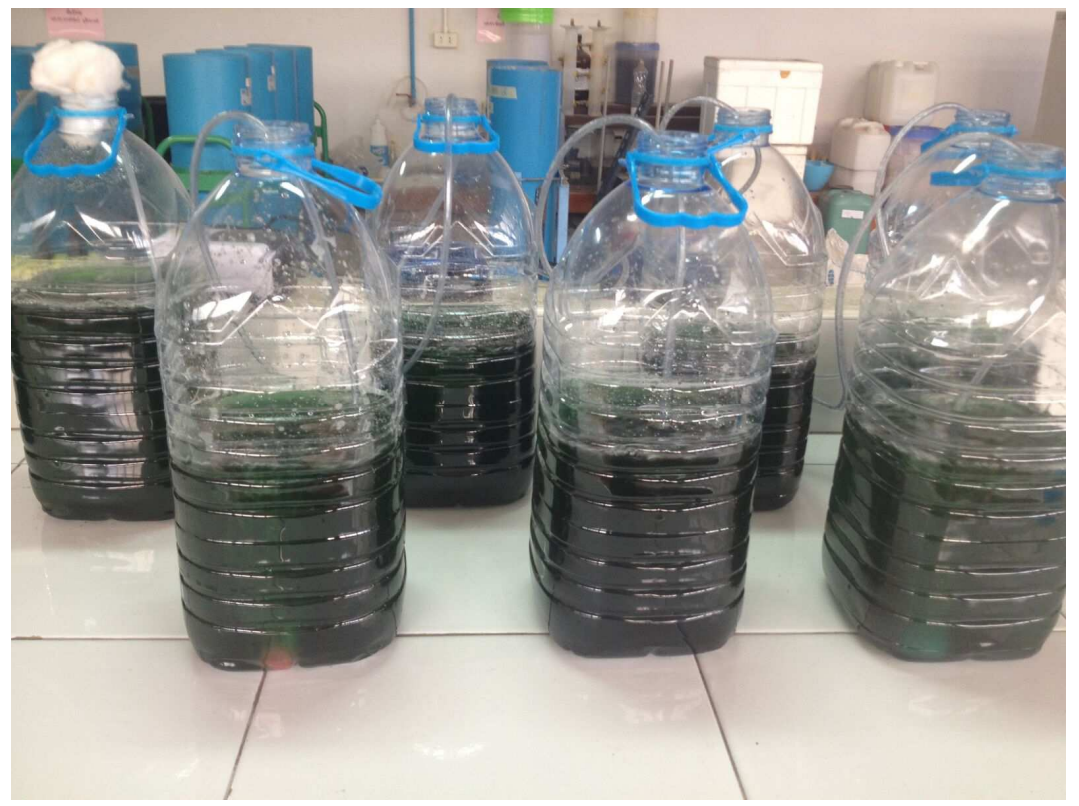

Fig. 2: The Oscillatoria sp. cultivation 


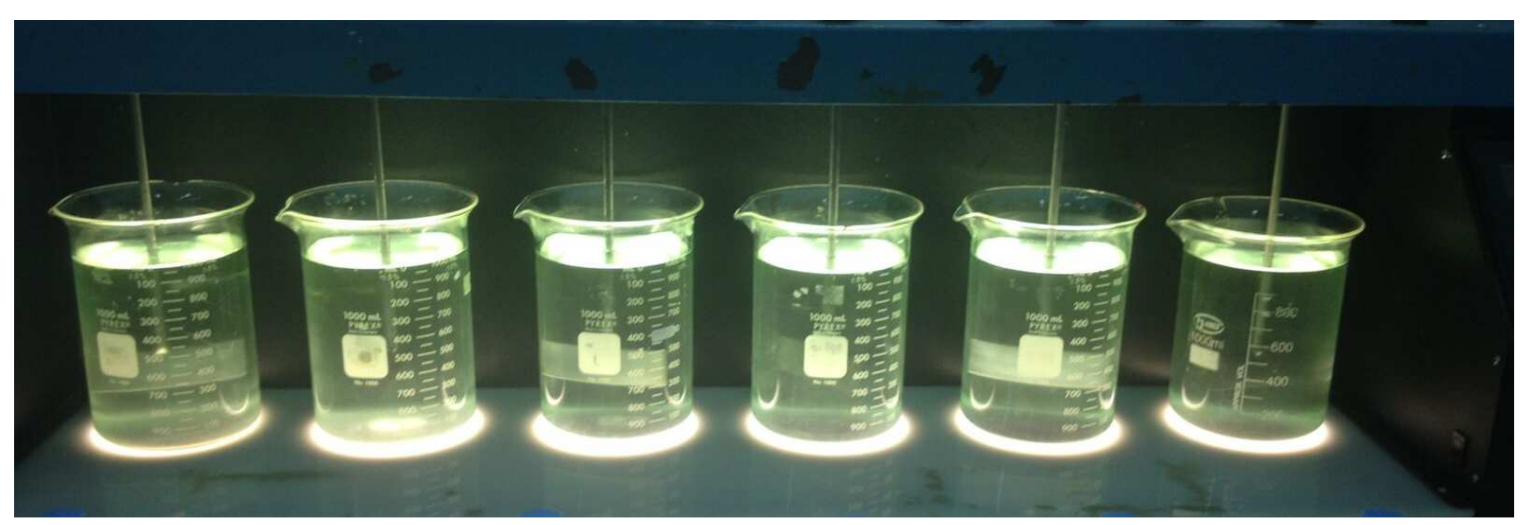

Fig. 3: The chemical coagulation

Table 1: The characteristics of synthetic raw water with Oscillatoria sp. cell

\begin{tabular}{llll}
\hline & Amount of Oscillatoria $\mathrm{sp} .(\mathrm{cell} / \mathrm{mL})$ & & \\
& - & 10,000 & 15,000 \\
\hline Characterisation & 5,000 & $7.0-7.2$ & $7.2-7.5$ \\
1. $\mathrm{pH}$ & $7.2-7.4$ & $197-214$ & $252-342$ \\
2. Chlorophyll A $\left(\mathrm{mg} / \mathrm{m}^{3}\right)$ & $97.4-105$ & $25-32$ & $25-27$ \\
3. Alkalinity $\left(\mathrm{mg} / \mathrm{L} \mathrm{as} \mathrm{CaCO}_{3}\right)$ & $25-31$ & 9 \\
\hline
\end{tabular}

\section{Synthetic Water}

The synthetic raw water is prepared as per the data collected from the Southern Region Industrial Estate, Songkhla Province, Thailand. The distilled water is diluted with the high amount of Oscillatoria sp. The amount of Oscillatoria sp. in these experiments is 5,000, 10,000 and 15,000 cell $/ \mathrm{mL}$. The characteristics of synthetic raw water are shown in Table 1. The $\mathrm{pH}$, chlorophyll A and alkalinity were analyzed for various amount of Oscillatoria sp. The result shows that the increasing amount of Oscillatoria sp. provided the increasing amount of chlorophyll A. However, the $\mathrm{pH}$ and alkalinity are not increased when the amount of Oscillatoria $\mathrm{sp}$. is increased. The initial $\mathrm{pH}$ values of all samples are neutral because the raw water is prepared from the distilled water.

\section{Batch Procedure}

The chemical coagulation in these experiments used the jar test. It is followed the standard practice for a coagulation and flocculation testing of drinking water to evaluate the chemical dosages (APHA, AWWA and WEF, 1995). The synthetic raw water was filled in six beakers with $1 \mathrm{~L}$ each as shown in Fig. 3. The alum and $\mathrm{PACl}$ with alum as the chemical coagulants were added. The six-spindle multiple stirrer was used for mixing the contents of the six beakers. Then, the 1-min rapid stirring is occurred at $100 \mathrm{rpm}$, or the coagulation process. After rapid stirring, the 30-min slow stirring is occurred at $30 \mathrm{rpm}$, or the flocculation process. The final process is the $30-\mathrm{min}$ settling, or the sedimentation process. At the end of the settling process, each beaker was carefully siphoned off so that the sediment at the bottom of the beaker will not be disturbed. Finally, the treated water is separated from the Oscillatoria sp. flocs.

\section{Analytical Methods}

The $\mathrm{pH}$, chlorophyll A, alkalinity and algae cells of the synthetic raw water and the treated water after chemical coagulation process are analyzed. The $\mathrm{pH}$ is measured using a pH meter. The algae contents of the treated water are measured, indirectly using the analyzed chlorophyll A concentration, both and after the flocculation and settling processes. The chlorophyll A is measured by the spectrophotometry (Strickland and Parsons, 1972). Algae cell uses Sedwick-Rafter (S-R) counting chamber. The alkalinity is followed by the standard method (APHA, AWWA and WEF, 1995).

\section{Results}

The quantification in the synthetic raw water samples shows that the amount of Oscillatoria sp. was 5,000 10,000 and 15,000 cells $/ \mathrm{mL}$ before the chemical coagulation process. The jar test is used in these experiments, for determining the parameters for flocculation and settling. The flocculation is carried out on a six-spindle multiple stirrer unit with the stainlesssteel paddles. The alum doses were $40,50,60,70,80$ and $90 \mathrm{mg} / \mathrm{L}$. The ratios of PACl: Alum doses were 1:10, $3: 10,5: 10,3: 20,3: 30,3: 40,10: 10$ and $20: 10 \mathrm{mg} / \mathrm{L}$.

\section{Effect of $\mathrm{pH}$ on the Chemical Coagulation}

The Oscillatoria sp. presents the complex matrix of organic compounds in natural waters. The algae have important influences on many aspects of water treatment 
processes, including the performance of operations such as coagulation, filtration and oxidation. The mechanisms of algae removal by adding coagulants consist of two stages. First, the algae, which are colloidal material in the water, are neutralized. Second, the soluble compounds of the neutralization process are then removed due to the absorption of precipitated flocs (Randtke, 1988).

Figure 4 shows the trend of $\mathrm{pH}$ after the chemical coagulation using alum coagulant. The initial $\mathrm{pH}$ is around 7 (neutral). The $\mathrm{pH}$ is decreased after increasing alum dose. The increasing alum crystals due to increasing alum dose, results in an increasing of algae cell destabilization. Thus, the $\mathrm{pH}$ value is decreasing. The alum dose in the chemical coagulation can be explained through the double layer compression, charge neutralization, entrapment, adsorption and complexation (Matilainen et al., 2010). When the alum dose is increased, the $\mathrm{pH}$ decreases. Thus, the alum dose and $\mathrm{pH}$ are linked (Gone et al., 2008). For alum coagulation, it is a concern because alum can be toxic to aquatic species due to decreasing $\mathrm{pH}$.

Figure 5 shows the trend of $\mathrm{pH}$ after $\mathrm{PACl}$ with alum coagulations. The initial $\mathrm{pH}$ is around 7 (neutral). When the increasing the alum dosed, the $\mathrm{pH}$ is decreased due to the increasing alum crystals. When increasing $\mathrm{PACl}$ and decreasing alum dosed, the $\mathrm{pH}$ is increased. The treated water is slightly neutral.

The optimization of the coagulation process occurs under an acidic condition between the isoelectric point of the coagulants such as $\mathrm{pH}$ 4.5-5.5 for Fe based coagulant and pH 5-6 for Al based coagulant (Sharp et al., 2006).

\section{Effect of Alkalinity on the Chemical Coagulation}

The trend of alkalinity after the chemical coagulation shows in Fig. 6. The trend of alkalinity is related to the alum dose and amount of Oscillatoria sp. cell. These results of alkalinity caused the decreasing in the $\mathrm{pH}$ value after increasing the alum coagulant.

The use of alum as a coagulant reduced the $\mathrm{pH}$ and alkalinity of water, as shown in Fig. 4 and 6 . The experiment showed that the $\mathrm{pH}$ value was reduced after settling with alum. When alum is added, the $\mathrm{pH}$ and alkalinity of water tend to decrease. Because alum is added in the sample, the reaction is broken down into cations and negative ions. Aluminum ions from $\mathrm{Al}_{2}\left(\mathrm{SO}_{4}\right)_{3}$ are surrounded by water molecules, becoming $\mathrm{Al}\left(\mathrm{H}_{2} \mathrm{O}\right)_{6}{ }^{+3}$, where hydrogen ions $\left(\mathrm{H}^{+}\right)$react with alkalinity in water. $\mathrm{The} \mathrm{Al}(\mathrm{OH})_{3}$ is main factor to decreases $\mathrm{pH}$ and alkalinity (Viraraghavan and Wimmer, 1988).

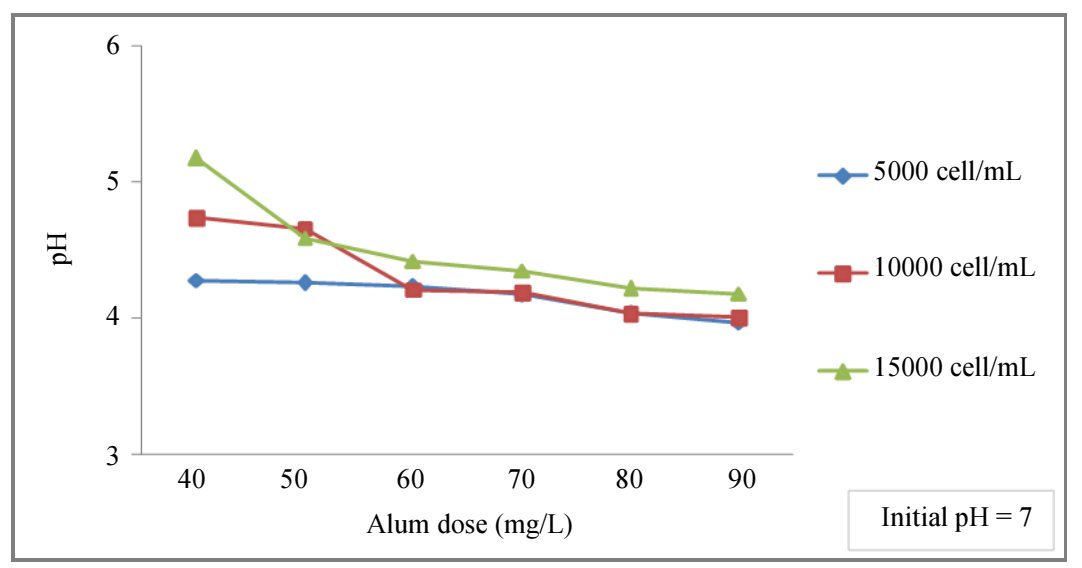

Fig. 4: Effect of alum dose on $\mathrm{pH}$

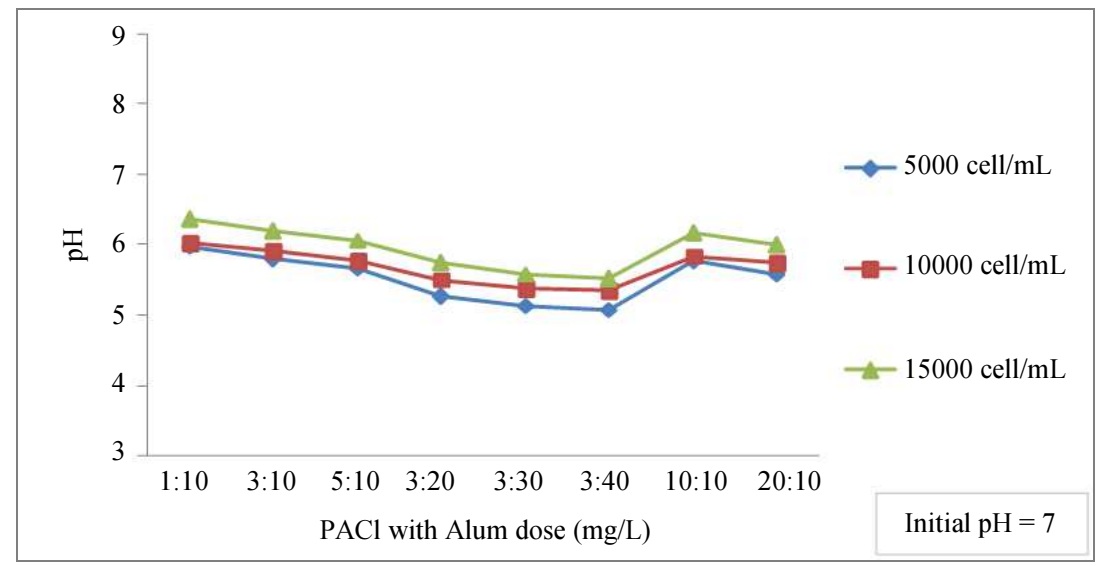

Fig. 5: Effect of $\mathrm{PACl}$ with alum dose on $\mathrm{pH}$ 


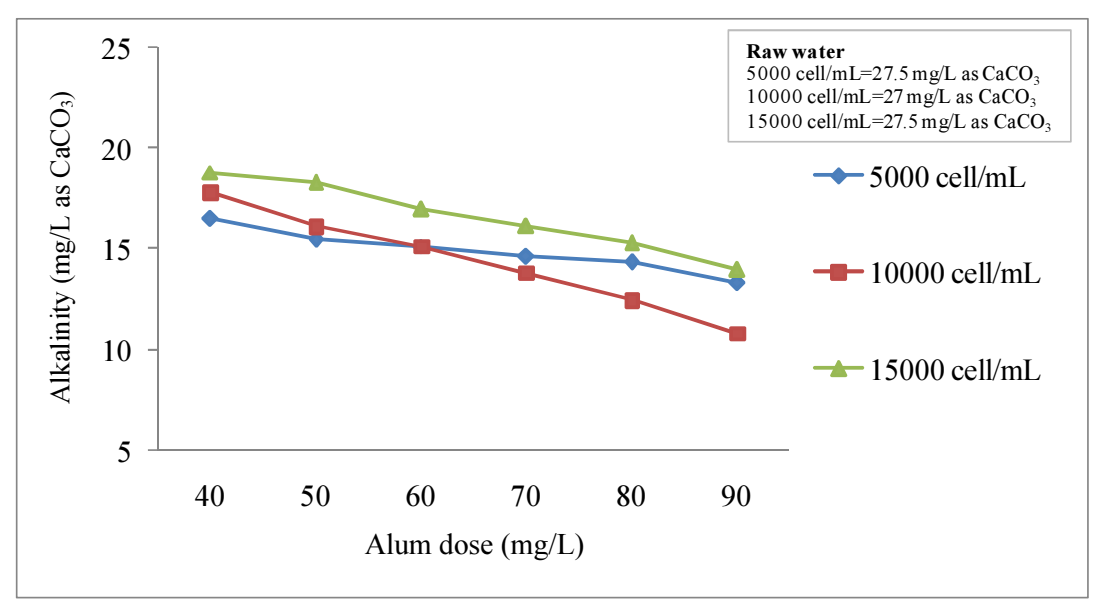

Fig. 6: Effect of alum dose on alkalinity

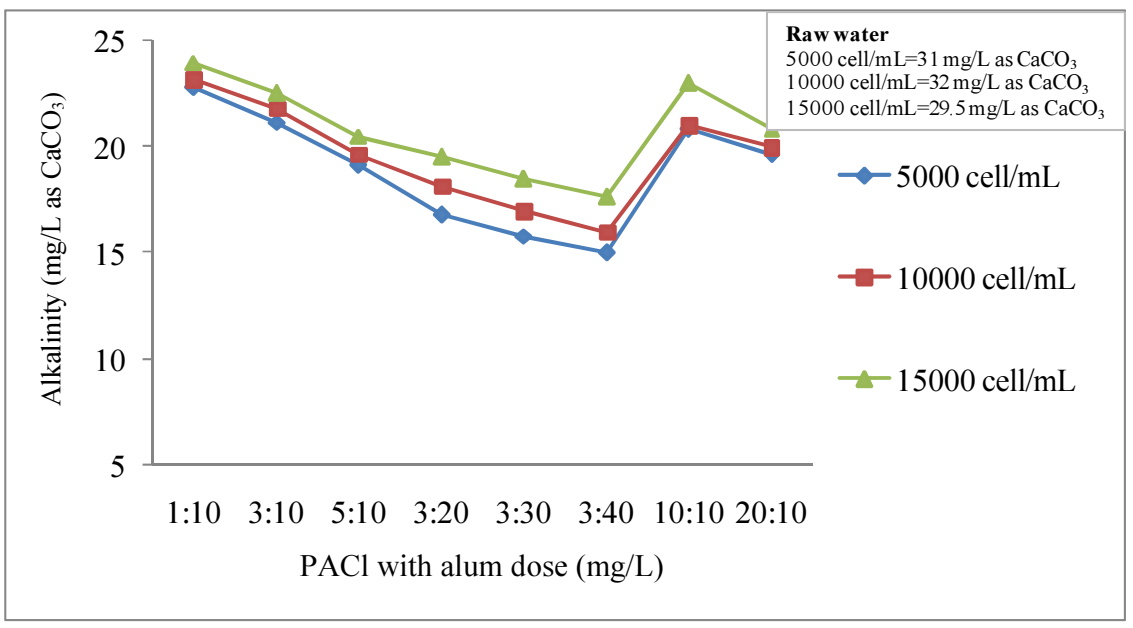

Fig. 7: Effect of $\mathrm{PACl}$ with alum dose on alkalinity

The effect of PACl with alum as co-coagulants on alkalinity of sample is shown in the Fig. 7. When the cocoagulant doses increased, the $\mathrm{pH}$ of treated water decreased. The salts of coaulant is formed aqua metallic ions as soon as the coagulant is added to the raw water. Then, the increasing ion in the system results in the decreasing of the $\mathrm{pH}$ value. Furthermore, the alkalinity which is related to the $\mathrm{pH}$ value is also decreased.

\section{Algae Cell Removal Efficiency on the Chemical Coagulation}

The alum is an inorganic coagulant. It has been and remains the most common coagulant for water treatment. In chemical coagulation, the floc quantity is determined by the charge density. The larger the algae cell size, the more floc is required for efficient chemical coagulation. The use of alum destabilizes and increases the size of the particles which will increase the algae floc size. The algae flocs are larger, rigid and settled well when adding more alum coagulant. The Fig. 8 shows the alum reduced the algae cell content effectively by flocculation and settling. The results shows that increasing the alum provided the increasing algae cell removal efficiency in all of various concentration of algae. The $40 \mathrm{mg} / \mathrm{L}$ of alum dose is the minimum alum dose, which removed $95 \%, 90.5 \%$ and $93.5 \%$ of algae cell for $5,000,10,000$ and 15,000 cell of algae cell $/ \mathrm{mL}$ of raw water, respectively. The $90 \mathrm{mg} / \mathrm{L}$ of alum dose is the maximum alum dose, which provided $98 \%$ of alage cell removal for all of 5,000, 10,000 and 15,000 cell of algae cell $/ \mathrm{mL}$ of raw water. The optimal alum concentration that is required to effect maximum flocculation depends on the amount of algae. The maximum of $90 \mathrm{mg}$ of alum/L of raw water is sufficient to clarify all the Oscillatoria sp. examined (98\% removal efficiency) for all various amount of algae cells. 
The results presented in Fig. 9 showed that the cocoagulant between $\mathrm{PACl}$ and alum doses could remove the algae cell. The similar Oscillatoria sp. removal efficiency can be achieved using PACl and alum does as co-coagulant dose and alum dose. However, the co-coagulant does is more efficient because the amount of $\mathrm{PACl}$ with alum does used is less than that of the alum does alone. The algae cell removal efficiency of $\mathrm{PACl}$ with alum does as cocoagulant does shows the same trend for all ratios. The ratio of $\mathrm{PACl}$ with alum dose at 1:10 by weight, provided the best algae cell removal for treating 5,000 to 15,000 cell/mL of Oscillatoria $s p$. concentration. The 1:10 ratio of $\mathrm{PACl}$ with alum dose contains $1 \mathrm{mg}$ of $\mathrm{PACl}$ and 10 $\mathrm{mg}$ of alum in $1 \mathrm{~L}$ of raw water. The increasing of $\mathrm{PACl}$ in co-coagulant dose resulted in a lower algae cell removal efficiency. The lowest algae cell removal efficiency is at $94 \%$ for 20:10 of $\mathrm{PACl}$ with alum dose.

\section{Chlorophyll A Removal Efficiency on the Chemical Coagulation}

The chlorophyll is essential for the photosynthesis. The majority of chlorophyll is to absorb the light and transfer that light energy. The chlorophyll $\mathrm{A}$ is a large molecule that has a porphyrin ring with magnesium atom at its center. It is the pigment that interacts directly with the light requiring the reactions of the photosynthesis. Therefore, the chlorophyll $\mathrm{A}$ is the principal photosynthetic pigment. The chlorophyll A removal shows the same trend in Fig. 10 after the chemical coagulation using alum dose and $\mathrm{PACl}$ with alum dose. The optimal alum concentration that is required to effectively maximize the flocculation depends on the concentration of chlorophyll A. The flocculation and settling processes are faster when using the alum concentration that is higher than that the optimal value.

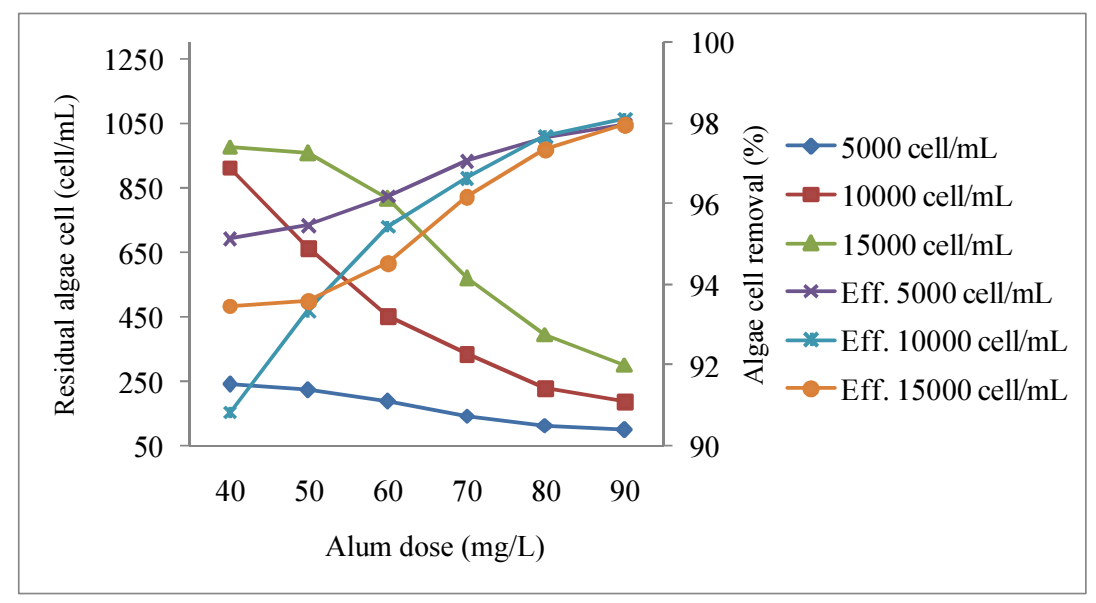

Fig. 8: Effect of alum dose on algae cell removal

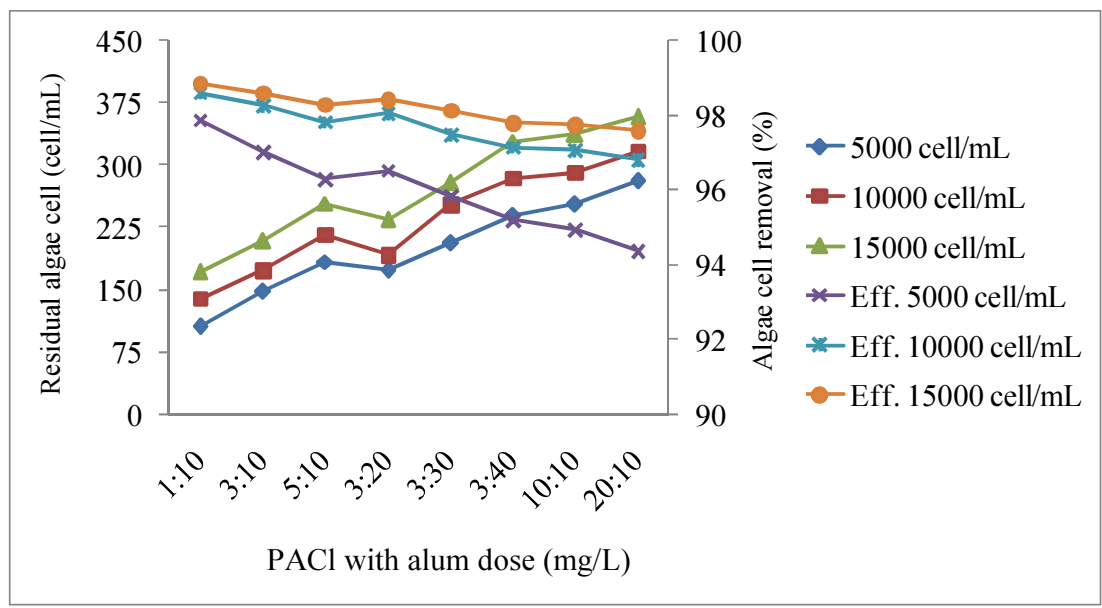

Fig. 9: Effect of $\mathrm{PACl}$ with alum dose on algae cell removal 


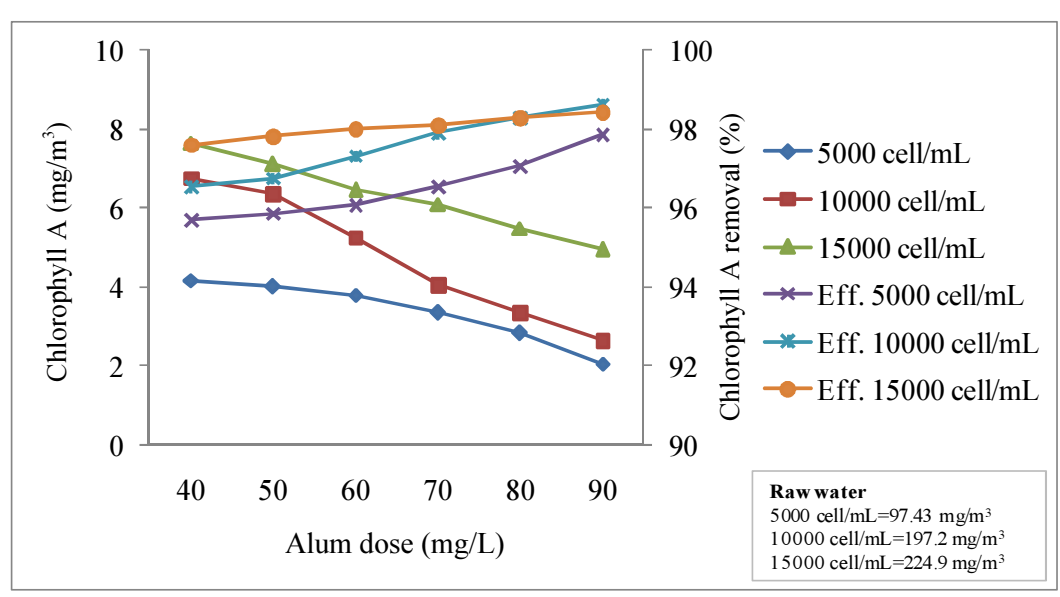

Fig. 10: Effect of alum dose on chlorophyll A removal

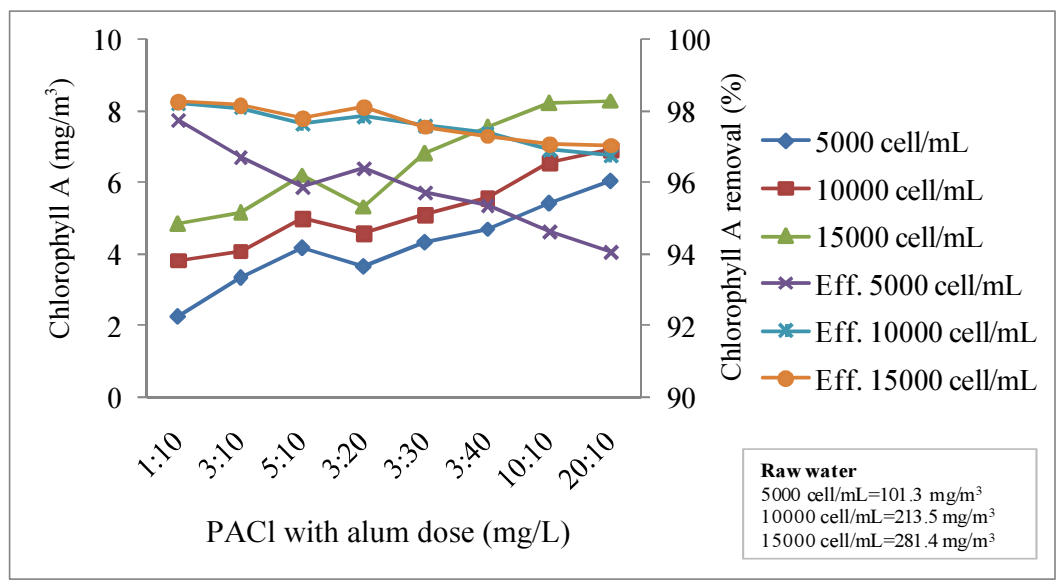

Fig. 11: Effect of $\mathrm{PACl}$ with alum dose on chlorophyll A removal

The results show that the three raw water concentrations of 5,000,10,000 and 15,000 cells $/ \mathrm{mL}$ of Oscillatoria sp. concentration are the most likely to remove algae in the same direction. The amount of algae and chlorophyll A decrease due to the increasing of alum. The increasing of alum breaks the stability of the algae particles. The algae can be approached and swarmed. The mechanism of the coagulation process to remove Oscillatoria sp. occurs when the alum is added to break the stability of the algae particles. The absorption and destruction of cell surface of Oscillatoria sp. will result in coagulation and precipitation when adding alum at a concentration higher than enough, the slow mixing of coagulation will produce crystalline alum. Thus, the efficiency of sedimentation increased (Ghernaout et al., 2010).

The chlorophyll A removal shows the same trend in Fig. 11 after the chemical coagulation using alum dose and $\mathrm{PACl}$ with alum dose. The ratio of PACl with alum dose is $1: 10$ by weight which is provided the best chlorophyll A removal for treating 5,000 to 15,000
cell/mL of Oscillatoria $\mathrm{sp}$. concentration. The 1:10 ratio of $\mathrm{PACl}$ with alum dose contains $1 \mathrm{mg}$ of $\mathrm{PACl}$ and 10 $\mathrm{mg}$ of alum. Thus, the operation cost of 1:10 ratio of $\mathrm{PACl}$ with alum dose is lower than that of $90 \mathrm{mg} / \mathrm{L}$ of maximum alum dose. When the co-coagulant dose is used the high efficiency can be achieved with less amount of dose in comparison with that of using alum dose alone. As a result, the cost of coagulant is lower than that of alum.

\section{Discussion}

$\mathrm{PACl}$ is a coagulant similar to alum, with a different in their the structures. The structure of $\mathrm{PACl}$ is larger than that of alum. Thus, PACl can contain more sediments and settle faster. Therefore, the amount required for $\mathrm{PACl}$ is less than that of alum. The coagulant is added to create crystals. The algae come into contact with the coagulant. Then, the coagulation process occurs. As a result, the stability of algae is destroied. From an enviromental point of views, using $\mathrm{PACl}$ was found to provide less environmnetal impact than using alum. 
The $\mathrm{pH}$ and alkalinity could affect the chemistry of coagulants, particularly the speciation distribution of coagulants after the chemical coagulation (Inchio et al., 2013). When the chemical coagulants are increased, the $\mathrm{pH}$ of the treated water is decreased, because the salt ions from salt coagulant will form the aqua metallic ions as soon as the chemical coagulants. Therefore, the salt ion is related to the system causing the $\mathrm{pH}$ value to decrease. According to these experiment results, the chemical coagulation is effective because the amount of alkalinity is sufficient for the reaction in the chemical coagulation process.

The optimal alum concentration that is required to effectively maximum the flocculation depended on the amount of algae. The $\mathrm{PACl}$ is the pre-polymerized inorganic coagulants and containing high positive charge. The charge neutralization is one of algal removal mechanisms by coagulation. Thus, the better performance of $\mathrm{PACl}$ in the algae removal is expected. It may be concluded that the $\mathrm{PACl}$ with alum doses are very effective in flocculating all these verities of algae contents, with the efficacy being influenced by algae cell concentration. Flocculation presumable takes place by charging neutralization and bridging between algae cells by $\mathrm{PACl}$ with alum chains, as in the case of other polyelectrolytes.

\section{Conclusion}

The chemical coagulation is commonly used in the water treatment. The effective reduction of algae, silt, clay, organic matter and bacteria in surface waters by coagulation, flocculation and settling is demonstrated. Thus, the chemical coagulation is a product of choice to remove the Oscillatoria sp. in the synthetic raw water. The chemical coagulation using the chemical coagulants exhibits the high efficiency in Oscillatoria sp. removal. The results show that the optimum alum coagulant is at $90 \mathrm{mg} / \mathrm{L}$ for the chemical coagulation process. The optimum PACl: alum coagulants ratio is $1: 10$ by weight. The quality of treated water from PACl: alum coagulant is slightly higher than that of alum coagulant. The amount of $\mathrm{PACl}$ with alum coagulant dosage is significantly lower than the amount of alum coagulant dosage.

The chemical coagulation method using coagulants reduces the amount of Oscillatoria sp. in synthetic raw water. This simple method can be applied in the water treatment plant. In rural areas this method is economic and easy.

\section{Acknowledgement}

Authors would like to thank Sustainable Waste Management (SWM) team (ENG-58-2-7-11-0208-S), Faculty of Engineering, Prince of Songkla University, Thailand for the financial supporting.

\section{Author's Contributions}

Saowapak Thammasane: Designed the research plan, participated in all experiments and coordinated the data-analysis.

Thaniya Kaosol: Designed the research plan, participated in all experiments, coordinated the dataanalysis and contributed to the writing of the manuscript.

\section{Ethics}

This article is original and contains unpublished material. The corresponding author confirms that all of the other authors have read and approved the manuscript and there are no ethical issues involved.

\section{References}

APHA, AWWA and WEF, 1995. Standard Method for the Examination of Water and Wastewater. 19th Edn., APHA Inc., New York, ISBN-10: 0-87553-207-1.

Carmichael, W.W., 2001. Assessment of blue-green algal toxins in raw and finished drinking water. Denver, Colorado, AWWA Research Foundation and American Water Works Association.

Chorus, I., I.R. Falconer, H.J. Salas and J. Bartram, 2000. Health risks caused by freshwater cyanobacteria in recreational waters. J. Toxicol. Environ. Health-Part B, 3: 323-347.

DOI: $10.1080 / 109374000436364$

Chorus, I. and J. Bartram, 1999. Toxic Cyanobacteria in Water: A Guide to their Public Health Consequences, Monitoring and Management. 1st Edn., E \& FN Spon on Behalf of the World Health Organization, an Imprint of Routledge, London, ISBN-10: 0-419-23930-8, pp: 416.

Drikas, M., C.W.K. Chow, J. House and M.D. Burch, 2001. Using coagulation, flocculation and settling to remove toxic cyanobacteria. J. Am. Water Works Assoc., 93: 100-111.

DOI: $10.1002 / \mathrm{j} .1551-8833.2001 . t b 09130 . \mathrm{x}$

Ghernaout, B., D. Ghernaout and A. Saiba, 2010. Algae and cyanotoxins removal by coagulation/flocculation: A review. Desalinat. Water Treatment, 20: 133-143. DOI: $10.5004 /$ dwt.2010.1202

Gone, D.L., B. Kamagate and R. Ligban, 2008. Coagulation-flocculation treatment of a tropical surface water with alum for Dissolved Organic Matter (DOM) removal: Influence of alum dose and $\mathrm{pH}$ adjustment. J. Int. Environ. Applic. Sci., 3: 247-257.

Inchio, L., G. Shuyan, H. Xiangjun, L. Yanjin and M.M. Kai, 2013. Coagulation optimization using ferric and aluminum salts for treating high algae and high alkalinity source water in a typical North-China plant. Desalinat. Water Treatment, 51: 3361-3370. DOI: $10.1080 / 19443994.2012 .751158$ 
Matilainen, A., M. Vepsalainen and M. Sillanpaa, 2010. Natural organic matter removal by coagulation during drinking water treatment: A review. Adv. Colloid Interface Sci., 159: 189-197.

DOI: $10.1016 /$ j.cis. 2010.06 .007

Naz, S., S. Aktar and S. Md. G.G. Azam, 2015. Biofertilizer (Oscillatoria sp.) increases growth and yield of rice (BR-29). J. Chem. Bio. Phys. Sci. Sec. B, 5: 4199-4204.

Pumas, C., P. Vacharapiyasophon, Y. Peerapornpisal, P. Leelapornpisid and W. Boonchum et al., 2011. Thermostability of phycobiliproteins and antioxidant activity from four thermotolerant cyanobacteria. Phycol. Res., 59: 166-174.

DOI: $10.1111 / \mathrm{j} .1440-1835.2011 .00615 . \mathrm{x}$

Randtke, S.J., 1988. Organic contaminant removal by coagulation and related process combinations. J. AWWA, 80: 40-56. DOI: $10.1002 / \mathrm{j} .1551-8833.1988 . t b 03037 . \mathrm{x}$

Sharp, E.L., S.A. Parsons and B. Jefferson, 2006. Seasonal variations in natural organic matter and its impact on coagulation in water treatment. Sci. Total Environ., 363: 183-194.

DOI: $10.1016 /$ j.scitotenv.2005.05.032
Stewart, I., A.A. Seawright and G.R. Shaw, 2008. Cynobacterial poisoning in livestock, wild mammals and birds - an overview. Adv. Exp. Med. Biol., 619: 613-637. DOI: 10.1007/978-0-387-75865-7_28

Strickland, J.D.H. and T.R. Parsons, 1972. A Practical Handbook of Seawater Analysis. 2nd Edn., Fisheries Research Board of Canada, Ottawa, pp: 310.

Villareal, T.A. and E.J. Carpenter, 2003. Buoyancy regulation and the potential for vertical migration in the oceanic cyanobacterium Trichodesmium. Microb. Ecol., 45: 1-10. DOI: 10.1155/2013/196516

Viraraghavan, T. and C.H. Wimmer, 1988. Polyaluminium chloride as an alternative to alum coagulation: A case study. Proceedings of the Annual Conference on Canadian Society for Civil Engineering, (SCE' 88), pp: 480-498.

WHO, 1998. Cyanobacterial toxins: Microcystin-LR in drinking-water. Background Document for Development of WHO Guidelines for Drinkingwater Quality, Guidelines for Drinking-Water Quality, World Health Organization, Geneva.

WHO, 2015. Management of cyanobacteria in drinkingwater supplies: Information for regulators and water suppliers. WHO/FWC/WSH/15.03. 